Article

\title{
Cheat Electricity? The Political Economy of Green Electricity Delivery on the Dutch Market for Households and Small Business
}

\author{
J. A. M. Hufen \\ $\mathrm{QA}^{+}$Research and Consultancy, Boddens Hosangweg 83, 2481KX Woubrugge, The Netherlands; \\ hh@qaplus.info; Tel.: +31-172-601-473
}

Academic Editors: Michiel Heldeweg, Ellen van Bueren, Anna Butenko, Thomas Hoppe, Séverine Saintier and Victoria Daskalova

Received: 14 October 2016; Accepted: 19 December 2016; Published: 23 December 2016

\begin{abstract}
The European Commission's renewable energy directive introduced a market-based Guarantees of Origin (GO)-trade system that gives consumers the choice of buying "real" green energy. This has been successful, as the market share of Dutch households that buy green energy grew to $64 \%$ in 2015. However, societal organizations are dissatisfied with the green energy offered, categorizing it as "cheat" electricity. This article aims to solve this riddle of a successful product created under the GO-trade system but also heavily criticized. Research reveals a lively marketplace with buyers eager to buy green energy and energy producers offering a wide range of labels. Marketplace mechanisms are strongly influenced by political choices, and financial support for energy suppliers makes green energy a credible option. Societal groups, however, argue that the information provided is incomplete and misleading, that buying green energy does not impact positively on greenhouse gas reduction, and that better information and structural reform are required. The GO-trade system is strongly influenced by member states' national energy politics. Societal organizations have helped to optimize the implementation of the GO-trade system in the Netherlands, but they are not expected to be able to support the creation of a level playing field in which an optimal GO-trade system will flourish.
\end{abstract}

Keywords: renewable energy directive; directive 2009/28; green electricity; cheat electricity; Guarantees of Origin; market-based system

\section{Introduction}

\subsection{Background}

The liberalization process in energy markets over the last two decades offered the European Commission an opportunity to stimulate the introduction of a market-based system to buy green energy. Guarantees of Origin (GOs) are the keystone in the market-based system that should ensure the origin of "real" green energy. After the idea was launched in 2001, Directive 2009/28 elaborated the new system both for issuing, transferring, and cancelling GOs and for organizing issuing bodies and supervision. The idea of the renewable energy directive was that consumer preferences would influence the switch to reduce $\mathrm{CO}_{2}$ emissions as scheduled [1].

The market for households and small business that is the focus in this article opened in the Netherlands July 2001 before the market for all electricity products started. Since then, the consumption of green energy has grown steadily to a share of $64 \%$ of all households and small companies in 2015 [2]. Consumers were apparently excited by the idea of buying green energy and contributing to the mitigation of negative climate effects. Dutch households' enthusiasm was not, however, matched in any other European country. This is remarkable, considering the low share of renewable energy in overall Dutch consumption in comparison to that in the EU-27 countries [3]. 
Despite the success of green electricity in terms of increased Dutch market share, societal organizations' criticism of green electricity for households and small business made green electricity a contaminated market label in the Netherlands. Their argument was firstly that the market for green energy was not transparent because the information provided by companies offering green energy was misleading for consumers [4,5]. Furthermore, Dutch households buying green electricity would not in any way contribute to diminishing $\mathrm{CO}_{2}$ emissions. National media reported regularly that green energy as sold in the Netherlands did not contribute to diminishing $\mathrm{CO}_{2}$ emissions [6,7].

\subsection{What Is the Market-Based GO-Trade System in Directive 2009/28?}

In the Netherlands, a green energy certificate system started in the 1990s as a burden-sharing system used by energy companies to account for their part in renewable energy production. This private system, set up by the energy sector, was transformed into a public system under national legislation of the Ministry of Economic Affairs [8-10]. The new system was no longer used for the energy sector itself. It was operational from July 2001 as the first part of an energy market for households and small business was liberalized. Because of tax exemptions, the market for green electricity was popular amongst consumers but criticized for excessive stimulation and lack of supervision [11].

The Commission's idea was to give energy consumers the choice of buying green energy and thereby enhance consumption and production of renewable energy [1,12]. A European Commission directive proposed the introduction of a market-based system for issuing and trading green energy certificates; such trading fits well in the process of liberalizing energy markets. The system as proposed by the Commission included definitions of "green energy", rules about the process of issuing green certificates, trade in green energy, surveillance of the process, and the role of different participants [1,12]. In the Netherlands, the European system replaced the national trade system that had been in use for several years.

The Commission asked member states to take responsibility for the arrangements to enable renewable energy producers' requests for a GO to be accommodated. A GO is defined in article 1 as "an electronic document which has the sole function of providing proof to a final customer that a given share or quantity of energy was produced from renewable sources" [1]. The Commission obliged member states to set up an electronic system with high quality standards [1] (pp. 19-20). A GO is the equivalent of one megawatt of energy and is valid for a period of one year, after which it expires [1]. The GO administration should contain: the energy source, type of energy (electricity, cooling, heating), description of the production installation, whether the production of renewable energy was financially supported, unique identification number including date and country of issue [1,12].

The highlights of the GO-trade system as proposed in Directive 2009/28 are visualized in Figure 1. The Commission requires member states to set up a system of GO trade with an issuing body in a central position. Member states can designate organizations to act on their behalf to put in place appropriate mechanisms to ensure that GOs are issued, transferred, and cancelled [1]. The issuing body is supposed to be an organization that is independent of energy production, transfer, or supply.

The Commission obliges member states to create a system that confirms the origin of electricity produced from renewable energy sources. The GO market as set up by member states should meet high quality standards such as objectivity, transparency, and non-discrimination [1,12]. Member states should construct their own system to supervise the issuance, transfer, and cancellation of GOs. The Commission chose to be itself responsible for the supervision of the international GO-trade system.

Energy market liberalization makes each member state responsible for ensuring that its country's energy suppliers communicate essential information to customers [1,13]. Energy suppliers should explain every year: the contribution of each energy source to the overall fuel mix and information on the environmental impact (at least $\mathrm{CO}_{2}$ emissions and radioactive waste). A model of the label was developed in order to structure the communication between energy suppliers and consumers [14]. 
Since 2015, an element has been added in the Dutch electricity label: the origin of renewable energy in terms of the location of the production in or outside the Netherlands.

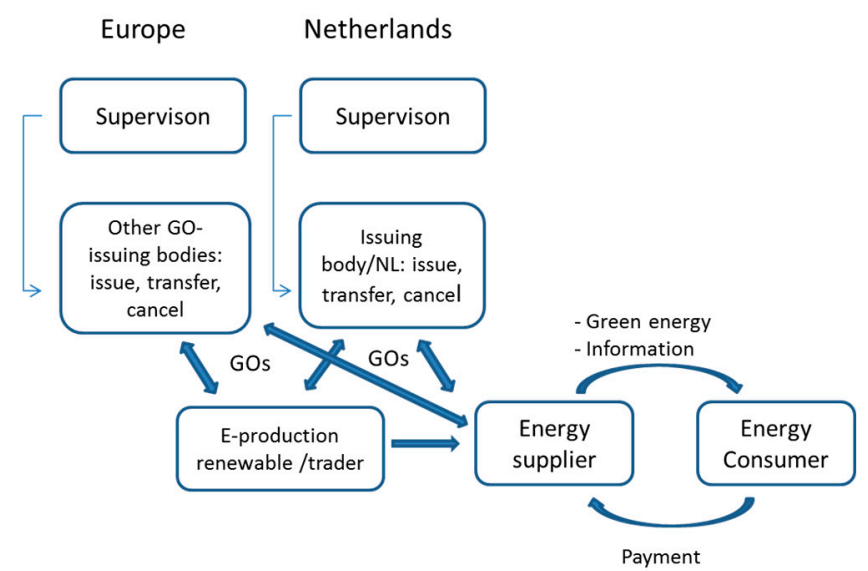

Figure 1. Design of the GO-trade system according to Directive 2009/28.

A consequence of the member states' high quality market-based GO-trade system is that GOs should be mutually recognized by participants. A member state has the right to refuse GOs from other countries according to the Commission. The refusal should in that case be explained to the Commission in terms of violations of the high quality standards $(2001 / 77 ; 2009 / 28)$. The renewable directive explicitly makes clear that GOs do not play a role in the monitoring of a country's performance as far as its goal attainment is concerned [1]. A country's performance is monitored by measuring its own production of renewable energy. The consumption of renewable energy does not influence a member state's performance.

\subsection{Theory and Policy Theory Regarding GO Trade}

The introduction of a European trade system for GOs is an interesting subject because of the connection to current debates and discussions about the liberalization of European energy markets, market-based trade systems, the role of citizens and consumers in the market system, and the relation between public actors and the energy production and supply sector. Below, we connect the GO-trade system with some ongoing discussions, theories, and conceptual models.

The design of a market-based GO-trade system can be interpreted as a development that is part of the liberalization of the European energy market. The realization of a competitive market and the protection of consumer interests was an important step in this process, but energy market liberalization is proving to be a difficult process. The old mechanisms in the centralized power of large companies and national preoccupations with the energy sector are persistent [15]. Governments had problems adapting to the realities of a liberalized market and chose their own interpretation during implementation [16]. The question here is whether the GO-trade system overcame these problems, as green energy trade seems to be a great success in the Netherlands. Were national interests not an obstacle in this case?

Dutch experiences with the predecessor of the GO-trade system showed that the design of a good trade system is demanding. An evaluation of the system revealed some weak spots: the quality of the administration, the administrator's independence of the energy sector, adequate supervision [11]. The Commission similarly found that the design of government-mandated market-based systems is not easy. The Emission Trading System (ETS) is a cornerstone in the Commission's climate policy, yet, according to some, design flaws limit its effectiveness [17]. In several periods, the $\mathrm{CO}_{2}$ prices were much lower than expected due to a lack of confidence in the system as well as uncertainty about political responses $[18,19]$. ETS implementation requires an active role on the part of the governments of major emitting countries to limit emissions [17]. 
In principle, green energy consumers have a key role in a liberalized energy system. The idea is that their preferences determine the supply of energy or renewable energy to be delivered. The Commission is well aware that the interests of consumers or other societal groups are subordinate in European decision-making processes [20]. The same goes for policy processes in the field of energy in the Netherlands [15]. The Commission points out that an active role for consumers and other groups is a major challenge that should be addressed. According to some, the active participation of these groups in decision-making must be translated into new criteria for legislation processes [21]. The failure to involve consumers' representatives or other societal groups in the design of the market-based GO-trade system could perhaps be a reason for their dissatisfaction with it. Additionally, it should be questioned why the success of the GO trade was not countered by the lack of consumer participation.

In policy sciences, there is growing awareness that government action is limited because of the networks in which private as well as semi-public and public actors participate [22]. This means that governmental activities like the design of a new system such as GO trade can only be understood when the actors directly and indirectly involved are considered. Jan Rotmans points out that, in Dutch energy transition, special attention needs to be given to the large energy companies in the market [23]. In his opinion, many private, semi-public, and public actors are involved in the energy market; the large energy companies in particular influence the outcomes of decision-making. Others see the combination of market-driven forces and public policy as the key to understanding energy consumption and production [24]. Energy market liberalization did not make government involvement obsolete [25].

\section{Methodology}

\subsection{Domain}

The domain of research is the implementation structure realized to implement Directive 2009/28. This structure is visualized in Figure 2.

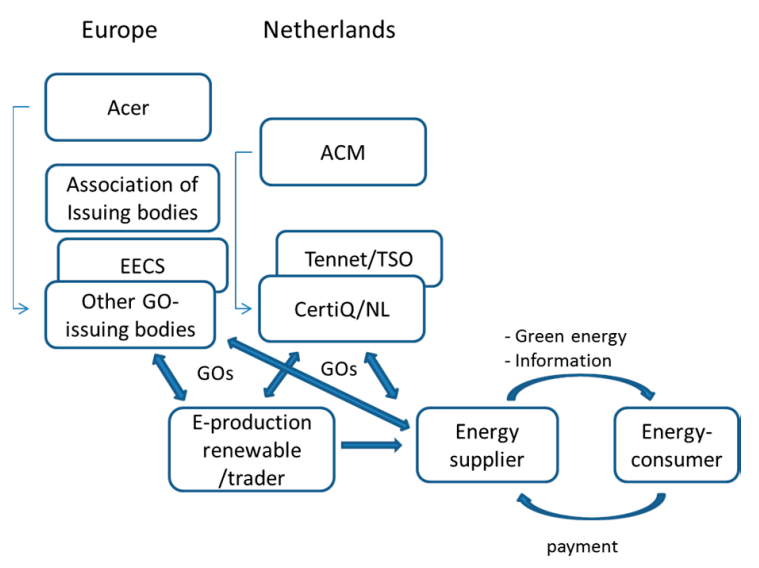

Figure 2. GO-implementation structure realized in the Netherlands as implemented on the basis of Directive 2009/28.

The starting point in the implementation structure is the marketplace in which energy suppliers and consumers meet. The energy supplier provides information about the offered energy labels as well as energy. Consumers are free to buy the energy; this means that they choose a contract type (e.g., annual contract), the price, and the origin of the energy (e.g., renewable energy). In the Dutch marketplace, the energy market is dominated by three energy suppliers that satisfy around $80 \%$ of demand [2]. In sum, around 7.7 million households use energy in the Netherlands [26]. This group accounts for around $20 \%$ of national energy consumption in the Netherlands [26].

CertiQ was established in July 2003 and is a 100\% subsidiary of the national Transport System Organization (TenneT). CertiQ has been appointed by the Ministry of Economic Affairs as the national implementing organization. CertiQ certifies renewable energy and issues GOs as evidence that the 
energy is truly green and describes the source: sun, wind, water, and biomass. When a GO is issued, CertiQ credits it to the account of a trader or a producer. Certificates issued by CertiQ can be traded within Europe. CertiQ is a member of the Association of Issuing Bodies (AIB), an international partnership of European Guarantee of Origin organizations.

AIB is an international platform of European organizations responsible for GO standards and measurement. The energy certificate system administrators across Europe are members of AIB, mostly transmission system operators, electricity regulators, and energy market operators. The AIB's purpose is to develop, use, and promote a standardized system: the European Energy Certificate System-EECS. EECS offers a framework for creating and transferring electronic documents. The harmonized standards enable the owners of EECS certificates to transfer them to other domestic and international accountholders. EECS is based on structures and procedures that ensure the reliable operation of an international certificate scheme.

The Autoriteit Consument en Markt (ACM) is charged with competition oversight, sector-specific regulation of several sectors, and enforcement of consumer protection laws. ACM aims to create a level playing field, where all businesses play by the rules and where well-informed consumers exercise their rights. ACM holds in its tool box: investigations, monitoring, publishing (sanction) decisions. ACM is open to contact with consumers and communicates actively through Consuwijzer. Consumers can file complaints against companies if they feel that economic law has been violated.

\subsection{Concepts, Goal, Research Questions, Method}

The main concepts in this article are defined in Sections 1.2 and 2.1.

Green electricity is electricity whose green credentials can be proved by a GO issued by a body like CertiQ. Suppliers buy GOs and cancel them to cover the green energy demand of their clientele. The issuing body is responsible for checking whether the renewable energy is actually produced, and a supervisor controls the issuing, transfer, and cancellation of GOs.

Green energy in the GO-market system as defined in the renewable energy directive is a product that is supposed to give an impetus to an energy transition in the electricity market. The market-based GO system is objective, transparent, and non-discriminative. Energy suppliers are supposed to inform consumers about the offered product.

"Cheat" green electricity is either electricity whose origin as renewable energy cannot be proved by a GO or electricity that does not comply with the standards and norms of the renewable energy directive.

The goal of this research is to describe and explain the success of Dutch households' consumption of renewable energy as well as to describe and explain the criticism regarding the lack of transparency and lack of additionality of the market-based GO-trade system.

Research questions:

Q1. How successful has the consumption of green energy (in terms of the size of the market share) been in the Netherlands, and how can we explain this in terms of the implementation mechanisms of the renewable energy directive and its broader context?

Q2. How have representatives of consumers and other societal groups criticized the GO-trade system, and how can we understand this criticism from their motives and their position in the implementation structure?

Q3. What actions were taken by societal groups as a follow-up to their criticism? Do their activities affect the market-based GO-trade system?

Our data collection strategy was to describe and analyze the green energy delivery process. We conceptualized this delivery process as an interaction process between actors in the implementation structure of Directive 2009/28 and actors in the environment such as national governments, consumer organizations, and other societal groups. We started with the renewable energy directive 
and organizations directly involved in the GO system and in addition addressed the broader implementation context.

The method included three steps. As government designed the GO system, we started with the description of the GO system as designed in the EC directive and national legislation (Step 1). Texts were gathered and analyzed. In several interviews, questions were asked about the directive and specific subjects therein.

We continued (Step 2) by describing and analyzing the marketplace in which the green energy was traded. During this step, statistical information about GO trade in the Netherlands and imports to and exports from the Netherlands were analyzed using information from CertiQ, AIB, and RECS. We used a combination of interviews and document research to describe and analyze the differences in the implementation structure. An interview was held with one of the three energy suppliers and representatives of the energy sector (Energie Nederland, RECS International, Vereniging voor Energie, Milieu en Water (VEMW). Because consumers as such cannot be observed, we used secondary material, especially questionnaires, to reconstruct consumers' purchases and understand their motives.

In addition, we reconstructed the broader context of the actors involved (Step 3) as the marketplace is a network that is open to influences by other actors:

- National government (Ministry of Economic Affairs);

- Consumers' representatives (Consumentenbond (CB), and Eigen Huis (EH)), nature and environmental groups (Greenpeace, Natuur en Milieuorganisatie, Wereld Natuur Fonds, and Wise), and other organizations: Hivos, Hier Opgewekt;

- $\quad$ Energy companies' representatives (Energie Nederland VEMV); and

- Representatives of the energy sector and consumers.

Finally, two experts were consulted: one specializing in green energy trade $(\mathrm{ECN})$ and one specializing in market design (TUD).

In sum, 21 interviews were held, of which 13 face-to-face and 8 interviews by phone. Several interviewees were contacted several times. In many cases, interviewees provided additional material that was analysed. Document research included statistics from CertiQ, AIB, RECS, and the Central Bureau of Statistics.

The answer to research question one is based on the research during Steps 1 and 2, although information from Step 3 was also used. The answer to research question one is presented in Section 3.1. The answers to research questions two and three are especially based on Step 3, but the results from Steps 1 and 2 were also used. The answer to research question two is presented in Section 3.2. The answer to research question three can be found in Section 3.3.

\section{Results}

\subsection{Successful Implementation of EC 2009/28, Large Demand and Supply}

Directive 2009/28 introduced a GO-trade system that set in motion an active trade in green energy. In the period 2003-2015, the green energy market share rose to $64 \%$ of every household as shown in Table 1. The development of the consumer market for green energy was obviously successful. Energy suppliers were able to accommodate Dutch consumers' large and rising demand. Consumers were very interested in green energy from the start, and eventually two out of every three consumers switched to it.

Table 1. Market share of green energy on the retail market in the Netherlands 2003-2015 (\%).

\begin{tabular}{cccccccccccccc}
\hline Year & 2003 & 2004 & 2005 & 2006 & 2007 & 2008 & 2009 & 2010 & 2011 & 2012 & 2013 & 2014 & 2015 \\
\hline $\begin{array}{c}\text { Market-share } \\
\text { green energy }\end{array}$ & 29 & 38 & 36 & 31 & 31 & 35 & 39 & 44 & 53 & 61 & 63 & 64 & 64 \\
\hline \multicolumn{1}{c}{ Sources: $[2,27-31]}$.
\end{tabular}


What is remarkable is green energy consumption's high market share in 2003. This is to some degree explained by the quick rise in demand for green energy when it was introduced under the regime of the Dutch predecessor of Directive 2009/28 [11]. After the first three years (2003) of green energy trade, one of every three consumers bought green energy.

Consumers' interest in green energy is not unconditional however, as research shows. The price of energy is by far the most important motive for consumers' energy choice [32]. Market research reveals that only a fraction of all consumers (20\%-25\%) are interested in green energy if prices are high [33]. The most important motive for consumers to switch to another energy contract is a better price. Around $10 \%$ of consumers mention the greenness of renewable energy as a motive for choosing another energy supplier [31]. Apparently, the large market share cannot be interpreted one dimensionally as resulting from a deliberate choice to reduce $\mathrm{CO}_{2}$ emissions.

A relevant question is how to explain why consumers buy renewable energy if prices are the most influential motive. Part of the answer is that the preference for renewable energy on the Dutch market was not obstructed by higher prices. Prices for renewable energy were competitive and sometimes even in the low price range because of successive governments' financial support to energy suppliers between 2001 and 2015. At first, tax exemptions (2001-2004) kept down the price of green energy [11]. Later on, production cost differences were mitigated by the MEP subsidy (2005-2006) and the SDE ${ }^{+}$ (2008-2015). The Dutch issuing body found that demand for GOs depended strongly on subsidies [34]. The tax exemptions were replaced by the MEP subsidy, which was abolished soon, and so the market dropped $20 \%$.

The rise in green energy's market share shows consumers' interest in green energy as well as the ability of energy suppliers to accommodate this demand. Each of the energy companies tried to secure its share of the green energy market with active marketing of their labels [35-37]. The Dutch energy suppliers grasped the opportunity offered by liberalization to provide green energy. Each of the larger energy companies (Nuon/Vattenval, Essent/RWE and Eneco) offered its green energy labels to the market. Some new energy suppliers entered the market offering renewable energy [35].

Statistics demonstrate that Dutch production covers around $28 \%$ of Dutch renewable energy demand. Around $75 \%$ of the remaining demand ( $72 \%$ of Dutch renewable demand) is covered by GO imports, especially water energy $[34,38]$. This strategy was a necessary condition for energy suppliers to accommodate consumer demand. In 2015, 70\% of the GO water energy imports were covered by water energy from the Scandinavian countries (Norway, Sweden, and Finland) and Iceland. Although the precise number of water energy imports and each country's share vary, the dominance of water energy in the imports from these countries is evident [39].

ACM interprets green energy as an essential product characteristic for competition for a homogeneous good such as electricity. To some extent, green energy was a lever to enter the market, although the market structure did not change [35]. The number of green energy labels was from the start more than sufficient to create choice [34]. Recently, energy companies have been using green energy labels to differentiate their prices strongly [2]. No societal organization filed complaints against GO trade as developed under Directive 2009/28. ACM's attitude as a supervisor regarding green energy was benevolent, and this gave green energy a competitive edge.

Although the green energy trade was criticized by national media and consumer organizations, CertiQ's GO administration developed into an undisputed institution. GOs were accepted in the market as proof that renewable energy was produced. CertiQ provided the independent institution that was needed after the energy sector itself had previously been completely responsible [11].

As explained above, national government provided different national schemes to support the demand for green energy. An additional support was a consequence of the match between GOs issued and national support schemes. GOs are an obligatory part of the submissions for support of energy production companies. This match between the two resulted in an accurate GO administration because almost all investments in renewable energy are covered by submissions. In comparison to other countries, the Dutch GO-trade system covers more than $90 \%$ of the production of renewable energy; this is the highest in Europe [39]. 
In sum, the answer to research question one is that green energy consumption in the Netherlands was successful because green energy became the most popular label bought by households and small business. Economic and political forces in the marketplace under the rule of the freshly introduced market-based GO system explain the success of green energy labels in the Netherland. A large proportion of Dutch households chose to buy green energy at competitive prices. Energy suppliers accommodated the demand by importing Scandinavian green energy in particular. The fact that energy suppliers could prove that their energy was green stimulated the market. National support schemes were important because they enabled energy companies to offer competitive prices. As price is the most important factor in consumers' choice of an energy label, this political action was crucial. The issuing body and the supervisor were satisfied about the GO system and the development of the market because in their opinion it operated within the legal rules.

\subsection{Criticism of the GO-Trade System: Transparency, Additionality}

\subsubsection{Lack of Transparency}

Directive 2009/28 presupposes that GO trade takes place in an objective and transparent market (see Section 2). In order to substantiate this transparency, GOs must contain descriptive information about, amongst other things, the origin of the renewable energy. Furthermore, energy suppliers are obliged to produce an electricity label for consumers every year with information about the sustainability of their energy supply as well as the share of renewable energy in the fuel mix.

In order to provide clarity about the meaning of the legislation, ACM developed a method to calculate the sustainability of energy supplied by suppliers active on the Dutch market. In addition, a model of companies' electricity label was developed in Dutch legislation. Since 2004, ACM checks the content of electricity labels and the calculation methods as the law prescribes. In their opinion, the transparency of the green electricity market is guaranteed by issuing well-defined certificates and the check on the energy suppliers' electricity labels. Their appraisal of the market as "objective" and "transparent" is based on the idea the Dutch energy suppliers operate within the boundaries prescribed by European and Dutch law.

Since liberalization, societal organizations like Consumentenbond and Greenpeace have monitored the energy market. After joint research by several societal organizations, their conclusion was that the green electricity market was not transparent. Energy suppliers did not provide the information necessary for consumers to choose the energy label that fitted their preferences. In their opinion, energy suppliers were inaccurate about the nature of the green energy delivered, especially about the background of the green energy. Figure 3 shows two pathways by which green energy can be delivered but that cannot be discerned in energy suppliers' offers.

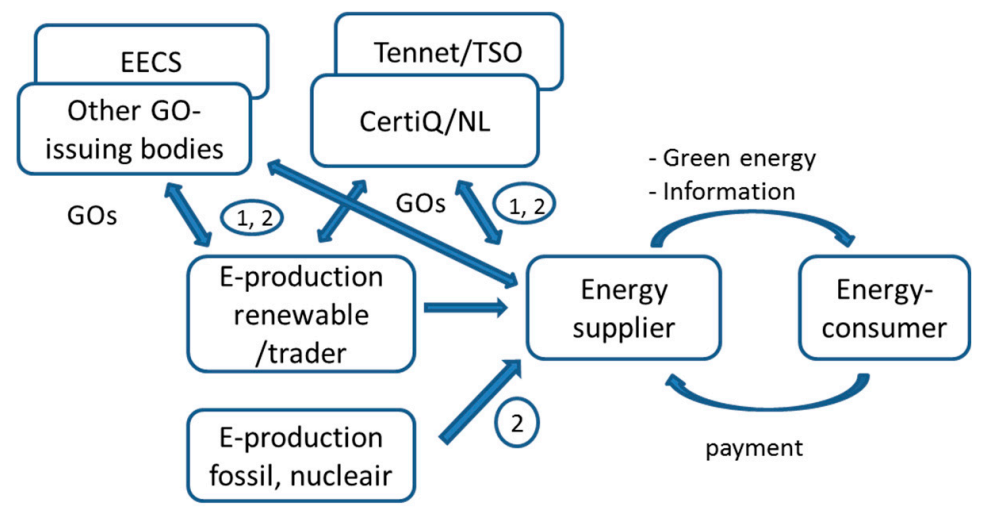

Figure 3. Green pathway (1) and red pathway (2) by which energy suppliers can deliver green electricity to consumers in the Netherlands. 
Green pathway (1): GOs are bought by a trader, energy producer, or energy supplier as legal proof that renewable energy was produced. An energy supplier buys sufficient renewable energy to cover its customers' green energy needs.

Red pathway (2): GOs are bought by a trader, energy producer, or energy supplier as legal proof that renewable energy was produced. An energy supplier buys a combination of fossil, nuclear, or renewable energy from an energy producer to cover its customers' energy needs.

The existence of two different pathways is a consequence of the existence of two separate markets: the electricity market and the GO market. Consequently, it is possible to sell to all consumers a $100 \%$ renewable energy label although the fuel mix is $100 \%$ energy from coals. The coalition of societal organizations claims that the distinction between the green and the red pathway to deliver green energy should be made explicitly clear in communications with consumers.

The information as communicated through the electricity label is, in their opinion, not sufficient to adequately inform consumers. Consumers are therefore not aware of the true nature of products and are therefore not able to choose the product that fits their needs. The coalition partners try to provide additional information to support the decision-making process.

Energy suppliers did not all respond in the same way to the criticism from the societal organizations. One of the big energy suppliers chose an active sustainability strategy in 2008, announced a number of measures, and cooperated with the societal organizations. The two other energy suppliers did not respond to the criticism, chose a strategy that defended the red pathway, and did not cooperate with the societal organizations.

Difficulties in understanding the products provided by energy suppliers are manifest in consumers' opinions, given that half of consumers say that the offer on an energy label is unclear [31]. In addition, a substantial proportion of consumers (around 40\%) think that buying green energy results in additional investment in renewable energy [32]. Furthermore, the nature of green energy is a difficult subject as one in every eight consumers thinks that green energy does not exist [40]. A group of consumers indicates that it has lost confidence in energy companies and sees them as an obstacle in the switch to a zero-emission society [41].

Market transparency is a matter of national interest, yet outdated from a European perspective. In 2006, soon after the market liberalization started, the Commission recognized the insufficient indication of the origin of electricity as a main deficiency of the European legal framework [42]. In an elaborate research project on the disclosure of market information, different European countries proved to be aware of the deficiencies of information disclosure about renewable energy. Not only were these deficiencies discovered, but also they have been the subjects of deliberation of possible improvements [43].

This subsection provides part of the answer to research question two. Representatives of consumers and other societal groups criticize the lack of transparency of the green energy market. In the opinion of societal groups, energy consumers are not adequately informed about the nature of green energy. Especially the red pathway for buying GOs to account for green energy delivery and buying a combination of fossil, nuclear, and renewable energy is not acceptable. From their perspective, it is not acceptable in a market-based system that consumers are not informed properly.

\subsubsection{GO-Trade System}

The idea of GO trade as introduced by the Commission is to enable consumers to buy green energy, thereby stimulating the consumption of renewable energy and supporting an energy transition. In the interviews, societal organizations expressed criticism of the effects of GO trade. In most interviews, the absence of any renewable energy consumption effect was mentioned. The existence of a second pathway to supply green energy without actually buying or producing renewable energy was seen as a problem of the GO-trade system.

The second pathway (red way) to supply renewable energy results in GO trade without a contribution to a switch or energy transition (see Figure 4). Several interviewees hinted at the absence 
of any effects of water energy imports, which is the most traded form of renewable energy through the GO-trade system [44]. Societal organizations referred especially to counties like Iceland, Norway, Sweden, and Finland. These groups obviously claim that the GO-trade system is not an effective instrument to realize countries' national overall goals regarding $\mathrm{CO}_{2}$-emission reduction.

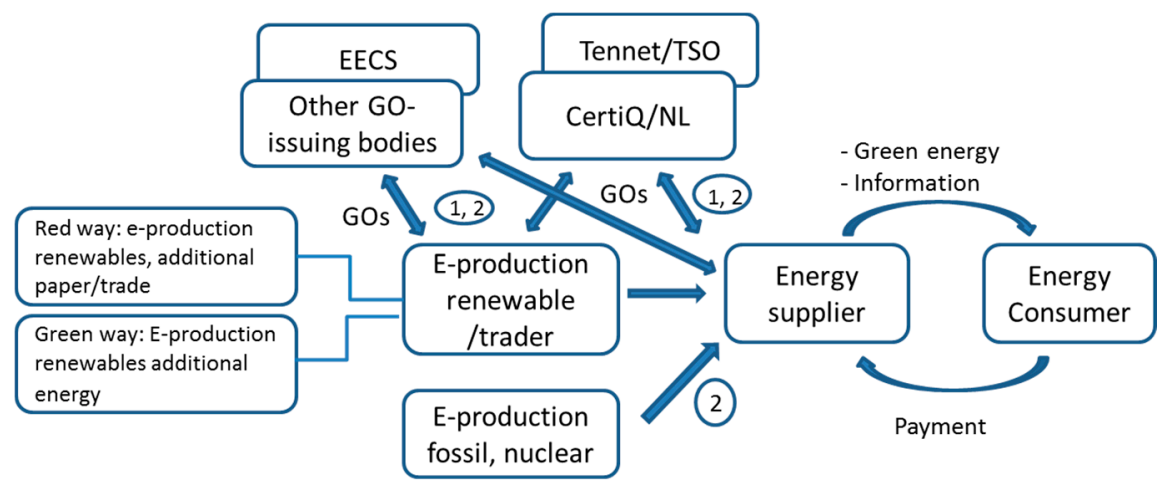

Figure 4. Estimated effects of GO trade according to societal groups in a green pathway (1) and a red pathway (2).

Closer inspection of statistics about GO trade can clarify the interviewees' opinion. Iceland produces all its energy needs by renewable energy and operates as an autonomous country. Energy imports to Iceland or exports from the island are not possible because there is no pipeline infrastructure to other countries. Iceland participates in GO trade as designed by the European countries and sells almost all GOs to interested energy companies or traders $[38,44,45]$. The inhabitants of Iceland are not interested in buying renewable energy, as indicated by the less than $1 \%$ of GOs that are redeemed [46]. The GO export provides additional revenues for the energy suppliers. Any stimulus on additional production or consumption is physical impossible because there is no pipeline infrastructure to the mainland.

The same lack of impetus on additional water energy production seems to hold for GO imports from Norway, Sweden, and Finland.

- The level of production of water energy in Norway, Sweden, and Finland after the introduction of Directive 2009/28 (2008-2014) did not change, as statistics of the International Energy Agency show [47]. The amount of water energy produced is different every year but does not rise over the course of years. Statistics of the Norwegian Ministry of Petroleum and Energy show the same pattern in Norway, being the country that exports the largest amount of water GOs [48].

- $\quad$ Prices for GOs are low (in 2015: around 22 eurocent) and therefore do not provide a stimulus for investment in water energy. Norway received an estimated $€ 2$ million for its GO exports, Sweden $€ 1.25$ million, and Finland $€ 0.5$ million [43,49]. GO trade gives energy companies or traders an additional source of income but is at this moment not an influential parameter in the behavior of private organizations in the energy sector.

- GO trade creates a reality on paper that differs from the usual trade in goods and services. For example: Norway produces $98 \%$ of its energy needs by means of water energy [46]. This is a convenient technology, using water and height differences provided by the country's natural terrain. Around $12 \%$ of its water energy is actually exported through the existing pipeline infrastructure to other countries, amongst which the Netherlands [50]. GO trade resulted for Norway in an export of $88 \%$ of Norwegian renewable energy [46]. Renewable energy is not a popular product, as around $22 \%$ of Nordic citizens buy renewable energy to cover their electricity needs. The Norwegian energy companies' GO-trade system is not of much interest to consumers or citizens. 
In interviews with the Ministry of Economic Affairs, CertiQ, and ACM, the existence of the two pathways was recognized. The imports and exports of Scandinavian GOs were interpreted by these organizations as in line with the European legislation in the renewable energy directive. The failure of the GO-trade system to stimulate additional production of renewable energy was not seen as a problem by the aforementioned organizations. The point of view of the Ministry of Economic Affairs matches with the procurement procedures of national and local governments. A substantial proportion of local and national governments' energy needs is covered by energy from the red pathway [51,52].

Societal groups' criticism regarding the effectiveness of GO trade refers to the conduct of specific countries not only in selling their GOs but also in keeping their energy. The idea of several societal groups is that the mechanisms of the market-based system do not contribute to realizing goals regarding $\mathrm{CO}_{2}$-emission reductions. In the interviews, several shortcomings in the GO-trade system were mentioned. The comments in these interviews are in line with the information in statistical data mentioned earlier in this section in relation to the lack of impetus for GO exports in Scandinavian countries.

In the first place, low prices for GOs were mentioned as an obstacle in the GO-trade system. Interviewees in the energy sector stated that GO demand is smaller than GO supply, with resulting low prices, as confirmed by RECS statistics [53]. Research reveals that Scandinavian GO prices varied in the period 2008-2015 between 0.10 eurocent and 0.25 eurocent [49]. Low prices are a structural problem in a market-based system because they do not result in an acceptable return on suppliers' investments.

Secondly, green energy producers in the two largest EU countries, that is, Germany and France, do not participate in GO submissions [39]. When countries other than France and Germany are added to the calculations, in sum $32 \%$ of energy production is not eligible for GOs because of national supports. These countries use the renewable energy directive to discourage GO submissions. According to article 15 of Directive 2009/28, national governments can chose to let energy producers lose the right to financial support for their renewable energy when the renewable energy is submitted for GOs. The revenues from GO trade are much lower than national financial support, and therefore energy producers do not participate in the GO-trade system. Another $20 \%$ is eligible for GOs but is not submitted. GOs that are issued cover $49 \%$ of the renewable energy produced [53].

Finally, GO trade as a market-based system aims to stimulate demand, whereas many national policies aim at energy production. Therefore, a dominant position for consumers in the market-based system cannot be realized. Several countries such as Germany and France stick to their reflex for the active involvement with energy supply experienced at the start of the market liberalization. The Netherlands is no exception, because Dutch tax exemptions and financial support for energy producers made the prices of renewable energy competitive. Directive 2009/28 sets the goals for renewable energy in terms of performance on energy supply, although while the policy for the directive was being developed a market-based system was discussed.

This subsection provides the other part of the answer to research question two. Representatives of consumer organizations and societal organizations criticize the GO-trade system because in their opinion it does not result in additional investments in renewable energy and does not contribute to an energy transition. The market-based GO-trade system results in very low prices that do not stimulate additional investments. Furthermore, more than half of renewable energy is not included in GO submissions. The largest economies in Europe choose active national involvement in energy policy instead of full cooperation in the market-based GO system.

\subsection{System of GO Trade under Pressure: Activities and Effects of Societal Groups' Criticism?}

The implementation of Directive 2009/28 in the Netherlands resulted in an intriguing situation. On the one hand, the demand for renewable energy rose to $64 \%$ in 2015 and became a very popular product amongst households and small business. On the other hand, green energy labels became a contaminated product, and green energy trade was criticized by consumer representatives as well as by nature and environmental groups and other groups. 
The question raised related to what societal groups did and the effect of their activities. The interviews and secondary research gave a perspective on this question. The societal groups most active in the field of green energy trade are characterized in Table 2.

Table 2. Characteristics of societal organizations active in the field of green energy trade.

\begin{tabular}{lllll}
\hline & Type & Focus & Constituency & $\begin{array}{c}\text { Related to } \\
\text { e-Sector }\end{array}$ \\
\hline 1. Consumentenbond (CB) & $\begin{array}{l}\text { Association of } \\
\text { consumers }\end{array}$ & National & $\begin{array}{l}\text { Consumers 2015: } \\
486,403\end{array}$ & No \\
\hline 2. Eigen Huis (EH) & $\begin{array}{l}\text { Association of } \\
\text { homeowners }\end{array}$ & National & $\begin{array}{l}\text { House owners: } \\
\text { 2015: 712, 954 }\end{array}$ & No \\
\hline 3. WNF & $\begin{array}{l}\text { Association of nature } \\
\text { friends }\end{array}$ & $\begin{array}{l}\text { National } \\
\text { International }\end{array}$ & Nature friends & Eneco \\
\hline 4. Greenpeace & $\begin{array}{l}\text { Environmental } \\
\text { pressure group }\end{array}$ & $\begin{array}{l}\text { National } \\
\text { International }\end{array}$ & Citizens & No \\
\hline $\begin{array}{l}\text { 5. Natuur-en } \\
\text { Milieufederaties (NME) }\end{array}$ & $\begin{array}{l}\text { Environmental } \\
\text { activity group }\end{array}$ & National & Nature friends & No \\
\hline 6. Wise & $\begin{array}{l}\text { Anti-nuclear action } \\
\text { group }\end{array}$ & National & $\begin{array}{l}\text { Anti-nuclear } \\
\text { antagonists }\end{array}$ & No \\
\hline 7. HIVOS & $\begin{array}{l}\text { Sustainability } \\
\text { 8. Hier Opgewekt (HO) }\end{array}$ & $\begin{array}{l}\text { Cooperation NME } \\
\text { and Hier } \\
\text { Klimatbureau }\end{array}$ & National \\
\hline
\end{tabular}

Wise = World Information Service on Energy; Hivos = Humanisch Instituut voor Ontwikkelingssamenwerking; TSO = Transfer System Organization; VNG = Vereniging Nederlandse Gemeenten (Association of Dutch local government).

Societal groups' activities aimed especially at improving the mechanisms of the market-based GO-trade system. The activities can be categorized as: (1) improving transparency; and (2) stimulating directly and indirectly the consumption of real green energy.

(a) Improving transparency

Because information on energy labels did not disclose enough information, Greenpeace and the Consumentenbond invested in research on the sustainability profile of energy suppliers $[54,55]$. The research focused on the following areas: (1) investments and disinvestments; (2) energy production; (3) energy sales; and (4) energy delivery. The outcomes of the research were firstly meant to inform societal groups about the sustainability of Dutch energy suppliers [37,56].

In addition, individual societal organizations invested in research on subjects like the number of green energy clients of the Dutch energy companies, price development of GO trade, among others. According to the societal organizations, this information is a more accurate description of the energy market. It supports the objective of green energy and the transparency of the market. The research created a solid knowledge base for societal organizations that gives additional information about the green energy market.

The knowledge resulted in a small improvement in transparency as the aforementioned research was translated into a useful measurement. The result of the sustainability profile, expressed on a scale of 1 to $10(1=$ not sustainable, 10 = very sustainable), was very brief and clear. The list of energy suppliers was classified into: frontrunners, peloton, and laggards [4,5]. This classification was used by all of the societal groups to inform their constituency and others interested. In addition, the Consumentenbond developed an electronic tool to support consumers' decision-making process. 
Furthermore, the societal organizations collaborated with members of parliament to change rules about the content of electricity labels. This resulted in a change in the rules concerning energy suppliers' communication with their clients. The origin of renewable energy now has to be communicated (in terms of produced in the Netherlands or not produced in the Netherlands).

The societal organizations draw attention to the need for further steps to improve transparency. A new method to improve information disclosure about the energy market is backed by the societal groups, the so-called ReDiss-method. It was developed by AIB members in cooperation with the issuing bodies of several countries [39]. The national supervisor, ACM, was also involved in the ReDiss-project. A coalition of societal groups, representatives of the GO-trade system, and the energy sector support the new idea.

\section{(b) Stimulating green energy trade}

Furthermore, societal groups were directly or indirectly involved in stimulating the purchase of "real" green energy:

In 2012, Wise introduced the concept of "cheat" electricity as a categorization for green energy bought especially in Scandinavia and Iceland (water energy). Since then, "cheat" electricity has been integrated in the idiom of Dutch consumers because newspapers and national media adopted the concept. Wise, Hier Opgewekt, and Greenpeace are very explicit in their communications about blaming energy companies that sell this "cheat" energy.

Wise and Hier Opgewekt are strict in their advice to consumers. If consumers choose green energy, the green energy labels that are not really green are excluded. "Not green" is interpreted by Wise as 75\% produced in the Netherlands and covered by Dutch GOs. Hier Opgewekt demands at least $75 \%$ production in the Netherlands. These organizations plead for consumers to choose Dutch green electricity.

Two societal organizations arrange collective procurement procedures for their members, using green energy criteria that are in line with those for "real" green energy. Large groups of consumers participate in these green energy procurement procedures. Thus far, 489,000 consumers have chosen another energy supplier as a result of Eigen Huis' collective procurement procedure.

The effect of these activities is not so much a destabilization of the market-based GO-trade system as a demand stimulus within the boundaries of the current rules. It is difficult to assess the effect of societal organizations on the green energy trade. However, a demand stimulus for Dutch green electricity seems to have occurred after the activities of societal organizations since 2012 [2]. Energy suppliers offer substantially more Dutch green energy labels than before [2]. In the period 2012 to 2016, the price of GOs for Dutch wind energy and Dutch sun energy rose considerably [57]. It seems that the societal organizations have influenced the green energy market and the GO market effectively.

The different organizations in the GO-implementation system do not agree with the categorization of green energy as "cheat" energy. According to CertiQ, this categorization jeopardizes the GO system and puts pressure on it. According to CertiQ, Greenpeace and Wise's plea to buy Dutch GOs is not necessary because foreign GOs are a valid proof of the authenticity of the renewable energy. Energy suppliers complained to the ACM about categorizations like "cheat" electricity. Their grievances were not substantiated by official complaints that ACM would have to investigate and assess. Neither is ACM itself willing to investigate the categorization as a supervisor. The societal groups' communication is welcomed as an acceptable additional bit of information for consumers.

Societal groups have a pragmatic approach to improving the market-based GO-trade system. Although some of these groups operate in different countries, the international aspects are not under scrutiny. GO trade is seen as an imperfect system, but so far there is no lobbying about it in European decision-making processes.

The Ministry of Economic Affairs acts as loyal member state that implements the Commission's renewable energy directive as it is. The ministry is well aware of the difficulties regarding imports of green energy, as it was responsible for such imports under the green certificate system that preceded 
GO trade. Approval was not initially given for the import of green water energy, but, soon after, it was allowed as long as the energy was fed in on energy transport lines [8-10].

This subsection answers the third research question concerning the action of societal groups. Consequent to societal groups' criticisms, their main resulting activities are attempts to improve the transparency of the market and stimulate "real" green energy. Their activities contributed to an adaptation of the rules concerning the provision of information about green energy by energy companies. Furthermore, the demand for Dutch green energy seems to have been raised as a result of communication, advice, and collective procurement procedures for households. Prices for this type of GOs have risen lately. Thus far, no attention has been paid by societal groups to mitigating the flaws of the GO-trade system.

\section{Discussion}

Contradictory opinions regarding the Dutch green energy market for households and small business provided the starting point of our research. After more than a decade, green energy has become the most popular type of electricity bought by Dutch households. At the same time, green energy labels have become a contaminated product in the Netherlands. Societal organizations criticize the lack of transparency and the failure of the GO-trade system to contribute to $\mathrm{CO}_{2}$ reductions.

We have tried to understand the contradictory aspects of the GO-trade system by looking at the actors involved in the process of green energy delivery. The interaction between public, semi-public, and private organizations in the market-based GO-trade system elucidates the underlying mechanisms. Our research shows that market forces and political factors in the GO-trade system determine the dynamics of the market. Both the success and the criticism of the GO-based system are better understood in terms of the economics-politics dichotomy.

The idea of liberalizing the energy market was to support the economics in the system. The renewable energy directive (Directive 2009/28) opens up the possibilities of GO trade between energy suppliers, energy producers, and households. Economic forces incentivized energy suppliers to offer green energy labels from the start. The big three energy suppliers in the Netherlands responded quickly to the strong demand for the new products. Green energy labels were attractive to households, as demonstrated by the growing market share. The implementation of the directive by CertiQ supervised by ACM became an undisputed institution.

However, the success of the GO-trade system was not solely a market adaptation to demand and supply. The price of green energy was influenced by the Dutch government, which provided three different financial support measures in the period 2001 to 2015. These measures offered support to energy suppliers that compensated the additional production costs of renewable energy. It was therefore possible for energy suppliers to offer green energy at a competitive and sometimes even low price. As price is by far the most important factor in households' decision-making process, this was a critical factor. The impact of the governmental support proved to be critical, as demand dropped $20 \%$ when one of the three support measures became less attractive. Energy consumers are sympathetic towards green energy but are only to a limited extent willing to pay more for it. In the absence of governmental support, the Dutch share of green energy consumption would have been lower and in line with other European countries. Obviously, the dynamics in the GO market and its success result from the economic forces of the GO-trade system and the governmental support.

Economic and political forces are also determining factors in the failure of the GO-trade system to stimulate additional green energy production.

The GO-trade system stimulates energy imports and exports by producers and traders in different EU countries. For the Netherlands, GO trade was unavoidable because of the need to accumulate enough certificates to accommodate the national demand for green energy. Countries like Norway, with an abundance of renewable energy and low domestic demand, export GOs, and this provides around $€ 20$ million in additional revenues. The red pathway that many energy suppliers in the Netherlands use is legitimized by the trade system but does not stimulate additional production. 
Thus far, the accuracy of the competent bodies for issuing, transferring, and cancelling GOs has been criticized, as also the role of national supervisors.

The research in this article demonstrates some structural shortcomings in the GO-trade system that are in line with experiences with the liberalization of European energy markets as well as market-based systems like the ETS. The GO-trade system cannot contribute to additional renewable energy supply in Norway or any other country because the GO prices are too low, as was also clear in the ETS $[18,19]$. Low GO prices result in low revenues and do not stimulate investment in renewable energy.

Different political factors prohibit a harmonized implementation of Directive 2009/28. In the first place, national governments prefer to implement their own energy policy rather than actively participate in the market-based GO-trade system. Of the renewable energy produced, $32 \%$ is ineligible for GO trade because countries prioritize their own national support schemes [17]. National governments withdraw the right to financial support if energy suppliers submit a request for GOs. An additional $20 \%$ of renewable energy is not submitted for GOs; this seems to reflect a lack of interest in GOs. As less than $50 \%$ of energy production is covered by GOs, the market is obviously not perfect yet.

In the second place, national governments choose to stimulate renewable energy in their own style. The old reflexes of preoccupation with the energy sector exist in the GO-trade system as they did before energy market liberalization [15]. Lack of harmonization is a well-known obstacle in the liberalization process, and the GO-trade system is no exception to the rule. Neither the Dutch government, nor the German and French governments, have implemented the idea of market liberalization or active support of GO trade. Even the European Commission itself is not an exception. Directive 2009/28 explicitly does not include the outcomes of the GO system as a performance indicator for progress in renewable energy policy. Renewable energy production is used as a performance indicator-a fact that does not encourage the development of a liberalized market.

The Commission is aware that, in particular, large companies and governments play a major role in European decision-making, such as Directive 2009/28. Interestingly, societal organizations were important in the implementation of Directive 2009/28 in the Netherlands. Their role was both critical and constructive, because their involvement resulted in an improvement in the transparency of the green energy market. Because consumer organizations and other societal groups played an active part on the market, the GO prices for Dutch renewable energy rose. These groups improved the GO-trade system mechanism within the limits of the current rules. The case of the market-based GO-trade system supports the idea of an active involvement of societal groups $[21,58]$.

The constructive criticism of societal groups regarding the GO-trade mechanisms was translated into a probably successful attempt to add a more national color. However, their severe criticism of the market-based system deserves a greater audience than their constituency and Dutch consumers. The shortcomings of the GO-trade system are in line with structural problems encountered in the energy market liberalization process and in other market-based systems such as the ETS. The Dutch government is well aware of the problems because problems concerning green certificates were already manifest in the national trade system that preceded the GO-trade system. However, national energy policy persists in an approach of passive implementation of Directive 2009/28. Hopefully, the evaluation and amendment of the renewable energy directive will give some momentum to solving deficiencies in the GO-trade system.

In this article, we have studied the political economy of the Dutch green energy market for households and small business. We have identified political and economic factors that determine the introduction of the market-based GO system. Although our research focuses on the Dutch green energy market, we have also dealt with the international aspects of the GO market. The Netherlands can only account for their green energy sales because of the red pathway in which Scandinavian water energy (GOs) is imported. We would like to recommend an international study of the market-based system in all participating countries. To use the full potential of this market-based system, it is necessary to 
understand the dynamics of the GO-trade system and correct its flaws. The Dutch experiences are an interesting but small part of the puzzle.

The subject of this article lies at the crossroads of different debates, theories, and conceptual models. The outcomes of our research provide several ideas for theoretical elaborations. In the first place, analysis of the introduction of the market-based GO-trade system in the Netherlands clarifies that political factors such as national interests and limited harmonized implementation of Directive 2009/28 are important prohibiting factors. An international comparative study of the European GO system could be interpreted in terms of these experiences in European decision-making. Furthermore, the critical and very constructive role of consumer representatives deserves further attention. The Commission is well aware of its limits concerning the involvement of societal groups and citizens in European decision-making. This article demonstrates the added value of an active involvement of societal groups and should be followed up by an investigation of the potential of their involvement in other decision-making processes.

Acknowledgments: The author would like to thank $\mathrm{QA}^{+}$Research and Consultancy in Woubrugge for supporting this research project.

Conflicts of Interest: The author declares no conflict of interest.

\section{References}

1. European Parliament; Council of the European Union. Directive 2009/28/EC of the European Parliament and of the Council of 23 April 2009. Off. J. Eur. Union 2009, L140, 16-62.

2. Autoriteit Consument en Markt. Annual Report 2015; ACM: Den Haag, The Netherlands, 2016. (In Dutch)

3. European Environment Agency (EEA). Share of Renewable Energy in Gross Final Energy Consumption. Available online: http:/ / www.eea.europa.eu/data-and-maps/indicators/renewable-gross-final-energyconsumption-4/assessment (accessed on 21 December 2016).

4. Consumentenbond; Greenpeace; Hivos; Natuur \& Milieu; Vereniging Eigen Huis; World Wildlife Fund (WWF); WISE. Onderzoek Duurzaamheid Elektriciteitsleveranciers. 2014. Available online: http:/ / www.consumentenbond.nl/tests/bestanden/woning-huishouden/onderzoek-duurzaamheidelektriciteitsleveranciers2014.pdf (accessed on 21 December 2016). (In Dutch)

5. Consumentenbond; Greenpeace; Hivos; Natuur \& Milieu; World Wildlife Fund (WWF); WISE. Onderzoek Duurzaamheid Nederlandse Stroom-Leveranciers. 2015. Available online: https:/ / www.natuurenmilieu.nl/wpcontent/uploads/2015/10/Duurzaamheid_Leveranciers_rapport_2015.pdf (accessed on 14 October 2016).

6. Nieuwe Rotterdamse Courant Handelsblad (NRC). Groene Stroom Is nu Vooral Een Imago Kwestie. Available online: http://vorige.nrc.nl/opinie/article1880794.exe/Groene_stroom_is_nu_vooral_ imagokwestie (accessed on 14 October 2016). (In Dutch)

7. Volkskrant. Groene Stroom of Sjoemelstroom? 2015. Available online: http://www.volkskrant.nl/economie/ groene-stroom-of-sjoemelstroom a3821247/ (accessed on 21 December 2016). (In Dutch)

8. Ministerie van Economische Zaken (MEZ). Regeling Groencertificaten Elektriciteitswet 1998, Nr. WJZ 01022598. Staatscourant, 7 May 2011. (In Dutch)

9. Ministerie van Economische Zaken (MEZ). Brief van de Minister van Economische Zaken, Vergaderjaar 2000-2001, Kamerstuk 25097; No. 53; Staatsuitgeverij: The Hague, The Netherlands, 2001. (In Dutch)

10. Ministerie van Economische Zaken (MEZ); EZ. Wijziging Regeling Groencertificaten Electriciteitswet 1998, Nr. WJZ 01053730. Staatscourant, 26 October 2001. (In Dutch)

11. Algemene Rekenkamer. Groene Stroom; Algemene Rekenkamer: Den Haag, The Netherlands, 2004. (In Dutch)

12. European Parliament; Council of the European Union. Directive 2001/77/EC of the European Parliament and of the Council of 27 September 2001. On the Promotion of Electricity Produced from Renewable Energy Sources in the Internal Electricity Market. Off. J. Eur. Union 2001, L283, 33-40.

13. European Parliament; Council of the European Union. Directive 2003/54/EC of the European Parliament and of the Council of 26 June 2003 Concerning Common Rules for the Internal Market in Electricity and Repealing Directive 96/92/EC. Off. J. Eur. Union 2003, L176, 37-56.

14. Ministerie van Economische Zaken (MEZ). Regeling Afnemers en Monitoring Elektriciteitswet 1998 en Gaswet. Staatscourant, 14 July 2004. (In Dutch) 
15. Pront-van Bommel, S. Het Derde Energiepakket. Tijdschrift voor Europees en Economisch Recht 2010, 58, 455-467. (In Dutch)

16. Pront-van Bommel, S. (Ed.) De Consument en de Andere Kant van de Electriciteitsmarkt; Universiteit van Amsterdam, Centrum voor Energievraagstukken: Amsterdam, The Netherlands, 2010. (In Dutch)

17. Jones, B.; Keen, M.; Norregaard, J.; Strand, J. Global prospects and policy issues. In World Economic Outlook, World Economic and Financial Surveys, Globalization and Inequality; International Monetary Fund (IMF): Washington, DC, USA, 2007.

18. Grubb, M.; Brewer, T.L.; Sato, M.; Heilmary, R.; Fazekas, D. Climate Policy and Industrial Competitiveness: Ten Insights from Europe on the EU Emissions Trading System; Climate Strategies, The German Marshall Fund of the United States: Washington, DC, USA, 2009.

19. Energy Centre Netherlands (ECN). Nationale Energieverkenning 2015; ECN: Petten, The Netherlands, 2015. (In Dutch)

20. European Commission. Communication from the Commission Launching the Public Consultation Process on a New Energy Market Design, COM (2015) 340 Final; European Commission: Brussels, Belgium, 2015.

21. Alemanno, A. Unpacking the Principle of Openness in EU Law: Transparency, Participation and Democracy. Eur. Law Rev. 2014, 39, 72-90.

22. Klijn, E.H.; Koppenjan, J. Governance Networks in the Public Sector; Routledge: Abingdon, UK, 2016.

23. Rotmans, J. In Het oog van de Orkaan; Aeneus: Boxtel, The Netherlands, 2012. (In Dutch)

24. Arentsen, M.J.; Fuchs, D. Green electricity in the market place revisited. In Im Hürdenlauf zur Energiewende: Von Transformationen, Reformen und Innovationen; Brunnengräber, A., di Nucci, M.R., Eds.; Springer: Wiesbaden, Germany, 2014; pp. 201-214.

25. Pront-van Bommel, S. Een Redelijke Energieprijs, de Mythe van de Marktwerking; University of Amsterdam Press: Amsterdam, The Netherlands, 2012. (In Dutch)

26. Centraal Bureau voor de Statistiek (CBS); Rijksdienst voor Ondernemend Nederland (RVO). Protocol Monitoring Hernieuwbare Energie; CBS: The Hague, The Netherlands, 2015. (In Dutch)

27. Planbureau voor de Leefomgeving. Milieubalans 2012; Planbureau voor de Leefomgeving: Den Haag, The Netherlands, 2013. (In Dutch)

28. Centraal Bureau voor de Statistiek (CBS). Gebruik van Groene Stroom Neemt Toe. Available online: https://www.cbs.nl/nl-nl/nieuws/2015/27/sterke-groei-aandeel-hernieuwbare-energie (accessed on 21 December 2016). (In Dutch)

29. Algemeen Nederlands Persbureau (ANP). Populariteit groene stroom gedaald. Boerderij, 13 December 2006.

30. Energeia. Hoeveelheid Groene Stroom Klanten Stijgt Opnieuw. 2008. Available online: http://energeia.nl/ nieuws/2008/11/19/hoeveelheid-groene-stroom-klanten-stijgt-opnieuw-met-12-in-de-lift (accessed on 14 October 2016). (In Dutch)

31. Autoriteit Consument en Markt (ACM). Trendrapportage Marktwerking en Consumentenvertrouwen in de Energiemarkt (Tweede Halfjaar 2013); ACM: Den Haag, The Netherlands, 2014. (In Dutch)

32. Marketresponse Stand van Zaken op de Energiemarkt. Available via Autoriteit Consument en Markt. 2014. Available online: https://www.acm.nl/nl/download/publicatie/?id=12909 (accessed on 14 October 2016). (In Dutch)

33. Autoriteit Consument en Markt (ACM). Trendrapportage Marktwerking en Consumentenvertrouwen in de Energiemarkt (Tweede Halfjaar 2012); ACM: Den Haag, The Netherlands, 2013. (In Dutch)

34. CertiQ. Annual Report 2008; CertiQ: Arnhem, The Netherlands, 2009.

35. Nederlandse Markt Autoriteit. Een Markt Zonder Spanning; Marktmonitor, Ontwikkeling van de Nederlandse Kleinverbruikersmarkt voor Elektriciteit; Directie Toezicht Energie: Den Haag, The Netherlands, 2006. (In Dutch)

36. Nederlandse Mededigings Autoriteit. Monitor Kleinverbruikersmarkten Gas en Elektriciteit 2009; Energiekamer, Nederlandse Mededingings Autoriteit: Den Haag, The Netherlands, 2009. (In Dutch)

37. Afman, M.R.; Bles, M.; Schepers, B.L.; Wielders, L.M.L. Electriciteitsleveranciers in Kaart, Update 2015; Centrum voor Energiebesparing (CE) Delft: Delft, The Netherlands, 2015. (In Dutch)

38. CertiQ. Annual Report 2015; CertiQ: Arnhem, The Netherlands, 2016.

39. Association of Issuing Bodies. Annual Report 2015. 2016. Available online: http://www.aib-net.org/portal/ page/portal/AIB_HOME/NEWSEVENTS/Annual_reports (accessed on 14 October 2016). 
40. Hier. Een op de Acht Nederlanders Denkt dat Groene Stroom Niet Bestaat. 2016. Available online: https:/ /hier.nu/klimaatbureau/nieuws/persbericht-een-op-de-acht-nederlanders-denkt-dat-groenestroom-niet-bestaat (accessed on 14 October 2016). (In Dutch)

41. Ministerie van Economische Zaken (MEZ). Motivaction, Energievoorziening 2015-2050: Publieksonderzoek Naar Draagvlak voor Verduurzaming van Energie; Rijksoverheid: Den Haag, The Netherlands, 2016. (In Dutch)

42. European Commission. Rules Concerning Communication from the Commission on Prospects for the Internal Gas and Electricity Market COM(2006) 841 Final; European Commission: Brussels, Belgium, 2007.

43. Reliable Disclosure Systems for Europe. Country Reports: Norway, Iceland, Sweden, Finland. 2015. Available online: http:/ / www.reliable-disclosure.org/documents/ (accessed on 14 October 2016).

44. Association of Issuing Bodies. Newsletter 25. 2016. Available online: http://www.aib-net.org/portal/page/ portal/AIB_HOME/NEWSEVENTS/AIB_Newsletter\%2025.pdf (accessed on 14 October 2016).

45. Stichting Onderzoek Multinationale Ondernemingen. Kortsluiting op de Groene Electriciteitsmarkt; SOMO (Stichting Onderzoek Multinationale Ondernemingen): Amsterdam, The Netherlands, 2016. (In Dutch)

46. Reliable Disclosure Systems for Europe. Country Report: Iceland. 2015. Available online: http:/ /www.reliabledisclosure.org/upload/180-RE-DISSII_Country_Profile_IS_2015-06-26_Final.pdf (accessed on 14 October 2016).

47. Statistics of the International Energy Agency. Available online: https://www.iea.org/statistics/ statisticssearch/ (accessed on 19 November 2016).

48. Norwegian Ministry of Petroleum and Energy. Facts, Energy and Water Resources in Norway; Norwegian Ministry of Petroleum and Energy: Oslo, Norway, 2015.

49. Afman, M.; Wielders, L. Factsheet: Ontwikkeling Prijzen Garanties van Oorsprong; Centrum voor Energiebesparing (CE) Delft: Delft, The Netherlands, 2016. (In Dutch)

50. Statnet. Key Figures 1974-2012, Market and Operations. Available online: http://www.statnett. no/en/Market-and-operations/Data-from-the-power-system/Key-figures-1974-20121/ (accessed on 14 October 2016).

51. Hartlief, I.; Kiezebrink, V. Kortsluiting op de Groene Energiemarkt; SOMO (Stichting Onderzoek Multinationale Ondernemingen): Amsterdam, The Netherlands, 2016. (In Dutch)

52. Schmid, M.; Sledsens, T. Rijksoverheid E Sjoemelstroom; World Information Service Energy: Amsterdam, The Netherlands, 2016. (In Dutch)

53. Renewable Energy Certificates (RECS). Annual Report 2015. 2016. Available online: http://www.recs.org/ documents/annual-report-2015 (accessed on 14 October 2016).

54. Centre for Research on Multinational Corporations. Sustainability in the Dutch Power Sector. Fact Sheets Series. 2009 Update. Available online: http://www.greenpeace.nl/Global/nederland/report/2010/5/ sustainability-in-the-dutch-po-2.pdf (accessed on 14 October 2016).

55. Centre for Research on Multinational Corporations. Sustainability in the Dutch Electricity Sector. 2012. Available online: https://www.somo.nl/nl/duurzaamheid-in-de-nederlandse-elektriciteitssector/ (accessed on 14 October 2016).

56. Afman, M.R.; Bles, M.; Schepers, B.L.; Wielders, L.M.L. Electriciteitsleveranciers in Kaart, Updated 2014; Centrum voor Energiebesparing (CE) Delft: Delft, The Netherlands, 2014. (In Dutch)

57. Wielders, L.; Cherif, S.; Schepers, B.L. Groene Stroom per Product voor de Consumentenmarkt; Centrum voor Energiebesparing, Centrum voor Energiebesparing (CE) Delft: Delft, The Netherlands, 2014. (In Dutch)

58. Lavrijssen, S. Waarborgen voor de Energieconsument in de Energietransitie; Tilburg University: Tilburg, The Netherlands, 2016. (In Dutch)

(C) 2016 by the author; licensee MDPI, Basel, Switzerland. This article is an open access article distributed under the terms and conditions of the Creative Commons Attribution (CC-BY) license (http:/ / creativecommons.org/licenses/by/4.0/). 